\title{
On Practical Teaching Reform of Applied Electrical Engineering and Automation Undergraduate Major
}

\author{
-Discussion on Xi'an international university
}

\author{
Lixia Peng* \\ Engineering College \\ Xi'an international university \\ Xi'an, Shaanxi, China
}

\author{
Huiling Meng \\ Engineering College \\ Xi'an international university \\ Xi'an, Shaanxi, China
}

\author{
Gailian Zhang \\ Engineering College \\ Xi'an international university \\ Xi'an, Shaanxi, China
}

\begin{abstract}
To meet the standard of first-class professional construction and needs of training of applied talents of the economic development demand of northwest China, the problems in the practical teaching of electrical engineering and automation specialty in Xi'an international university were analyzed, the ideas and reform measures of the design in the training mode, teaching management, teaching contents, teaching methods and construction of teaching stuffs were summarized in this paper, it can provide experiment reference for practical teaching reform of engine ering applied talents in other major or university.
\end{abstract}

Keywords-electrical engineering and automation; practical teaching; first-class professional; reform measures

\section{INTRODUCTION}

Over these years, electrical automation is a significant symbol of the modernization of national economy and industrial production as electric power becomes an important material basis for developing production and improving the living standard of human beings. Therefore, the demand for electrical engineering professionals is rising, and the need of electrical engineering talents is more huge as the abundant resources in northwest region, especially in Xi'an, for which the manufacturing industry, which is concentrated as large number of Military enterprises mainly engaged in aviation, aerospace, weapons, and ships, and civil enterprises mainly engaged in the manufacture of heavy-duty automobiles and electronic products factories, is there.

With the rapid growth of the demand for electrical engineering and automation professionals, the development of the professionals cultivation is far behind. In China, the practical teaching of cultivating application-oriented professionals is weak [1, 2], while other foreign universities

Fund Project: 2017 Xi'an International University teaching reform Project: Research on the first-class professional practice teaching system of electrical engineering and automation(fund number: 2017B24) ,Research on College Students' innovation and Entrepreneurship Education in Applied Undergraduate Universities(fund number: 2017B26), Research on teaching and experiment of private universities based on Intelligent Computing(fund number: 2017B27). attach importance to the practical teaching, emphasize the combination of production, study and research.

For adapting the rapid development of modern manufacturing, it is important to innovate practice teaching mode, content, method, conditions, management, evaluation and so on to construct training applied undergraduate students basic ability, engineering ability and innovation ability of multi-level practical teaching system to improve the quality of teaching for talents, it is a strong practicality subject to the development of manufacturing.

\section{Objective And Orientation of Cultivating} PROFESSIONAL TALENTS FOR ELECTRICAL ENGINEERING AND AUTOMATION OF Xi 'AN INTERNATIONAL UNIVERSITY

One clear goal, which promote the development of social, economic and higher education in Shaanxi Province, guide the development of private colleges and universities in talents cultivation for electrical engineering and automation in Xi'an international university. The goal points out the direction of the construction of electrical engineering and automation specialty. This professional serves local manufacturing industry in Shaanxi Province, with the aim of the development of first-class professional, the university cultivate applied specialized talents, who possess the innovative consciousness, could engaged power supply and distribution system in the domain of electrical engineering, automation control system, production equipment electrical control system design, construction, operation and technical renovation work, can also be used in electrical equipment manufacturing enterprises engaged in the work of product design, development, debugging and so on. 
III. MAIN PROBLEMS EXISTING IN THE PRACTICAL TEACHING OF ELECTRICAL ENGINEERING AND AUTOMATION IN XI 'AN FOREIGN AFFAIRS UNIVERSITY

In order to cultivate high-quality personnel in the critical era, the personnel training model should be followed on the basic guidance that innovate the training scheme for applied technology and skilled personnel training, and establish an optimal training program to improve practical skills and realizing the prefect transition from profession to industry, course content to professional standard, teaching process to production process[3]. As practical teaching proves the critical segment of teaching process, it should be an chief means to cultivate students' practical ability and an effective way and an vital guarantee to achieve the goal of cultivating applied professionals [4,5].

On the other hand, as an aim to e-stable the first-class discipline it is clear that the professional cultivation program should emphasizes the cultivation of students' ability and professional quality, attaches position to the agriculture of students' innovative spirit, practical ability and entrepreneurial ability, and actively explore new ways of jointly cultivating teachers by school and society.

Based on the training model applied in xi 'an foreign affairs college of electrical engineering and its automation practice teaching, the quality of personnel training significantly improve, but the patters is still some limitation. Such as old teaching contents, teaching methods singly, backward management mode, lack of professional teachers the teaching goal is not clear, the teaching design is not comprehensive. All of these problems need to be solved to reach the goal of the first-class professional construction standard.

\section{THE THOUGHTS ON CONSTRUCTION OF PRACTICAL TEACHING SYSTEM OF ELECTRICAL ENGINEERING AND AUTOMATION SPECIALTY}

From the concept of modern talent training, the applied talents are definitely well-developed talents. The practical teaching should be oriented to tamping the professional foundation, improving the engineering consciousness, highlighting the application of technology, strengthening the engineering practice ability and cultivating the innovation consciousness.

Due to this idea, XI'AN international university of electrical engineering and automation specialty presents a new practice teaching concept with a modern, integrated, multi-platform, multi-level education way.

According to the new notion, the personnel training should combine with regional economic development and take practical ability training as the main line throughout the personnel training, adhering to the concept of paying equal attention to both theory and practice and the coordinated development of production, education and research. Furthermore, it needs to establish three platforms: experimental teaching and research platform, engineering practice employment platform and innovation and entrepreneurship education platform, also needs to carry out practical teaching at four levels: basic experiment level, professional improvement level, comprehensive innovation level and skill training level.

Nevertheless, the contents of practice teaching should combine with industry development, vocational education, science and technology competition, scientific research, entrepreneurship and innovation. After all, the talent training model would gradually become theoretical combinations of theoretical and practical teaching, practical and innovative ability, in-class and out-of-class teaching.

\section{THE REFORM MEASURES OF PRACTICAL TEACHING OF ELECTRICAL ENGINEERING AND AUTOMATION SPECIALTY}

In view of the main problems existing in practical teaching in the training of electrical engineering and automation talents, the ideas of practical teaching system should be clarified, and the professional orientation and training objectives should be defined. XI'AN international university should vigorously promote the practical teaching reform in the professional development.

\section{A. Three highlights implemented in the teaching objectives}

The teaching objectives should be designed with three highlights: highlighting the students' ability to apply basic experimental knowledge, highlighting the students' comprehensive ability of practical operation, highlighting setting up students' innovative ability of scientific research thinking.

\section{B. Three projects outstand in teaching management}

The first project is the comprehensive practical training on campus. It require students assigned to different project teams during the process of comprehensive practical training on campus, the university can manage and evaluate different project teams. The project can not only improves the practical ability of students, but also strengthens the ability of solidarity, coordination and management.

The second project is the management mode call for oncampus production practice which should be corporatized, It require students are assigned to different groups during the oncampus production practice, assigned to different work positions, and held different job responsibilities, then the university assess the performance of the workshop, team, individual respectively. For example, in the PLC design studio set up in the experimental training center, students practice in the studio completely in accordance with the business operation mode of the enterprise, so that students can truly understand the role of work.

The third project is the employee management mode for students practicing outside. The mode also require students' going out for internship should completely comply with the requirements and management of enterprise employees, which mainly reflects the school-running concept of "ordering type" talent cultivation. 


\section{Three combinations highlighted in teaching content}

According to the actual teaching objects, the teaching content should highlight the application features, combine the enterprise project case with the course case, strengthen the cultivation of practical application ability, and keep up with the latest technology development and application.

At the same time, the traditional curriculum content should be changed to afford the demand of job skills. It means that the course content should be divided into a number of knowledge points, so as to change the previous way of teaching according to the link sequence of knowledge points. Instead, the skills required by the job need be divided into several levels, which knowledge points could to be integrated by different skills at different levels, and the teaching content will be arranged according to this scheme. In this way, the new model could combine professional education with innovation and entrepreneurship.

In the process of discipline education, students are guided to carry out scientific and technological innovation, and a software and hardware platform for teachers and students with innovative ideas to perform scientific and technological innovation activities be provided. For The final goal of applied undergraduates for the employment and entrepreneurship training the scientific and technological innovation projects is supported, and the business marketing planning and implementation been carried out.

\section{The combination of Teaching implementation and engineering practice}

In order to strengthen the connection between traditional theory teaching and practice application, the theoretical teaching content should be designed according to the practical application requirements, the content of the textbook should be updated according to the engineering needs and the teaching cases should be combined with the engineering cases to narrow the gap between the practice skills and the theoretical knowledge.

Furthermore, for meeting the actual production needs, the teaching method, management method and skill level of teachers should reach the same level as the engineers of the enterprise, the teaching process should strict its operation standard and process flow, as the same as the production process, and the design of the campus practice site should be consistent with the site of enterprise engineering.

\section{E. Improve the cognitive practice}

It is easy to understand that the professional cognition practice and the practical application of sensory introduction of the major could help students have an overall understanding of their major in a relatively short time, and lay a good foundation for the following study.

According of the concept, a goal of the new teaching model is to give students a preliminary understanding of the knowledge and skills they need to learn in their chosen major, and to help students understand what they have learned intuitively. And for strengthening students’ practical ability, in the new student's entrance stage, the new teaching mode carries out the practical teaching which takes precedence over the theoretical teaching.

\section{F. Integrate multiple teaching modes}

In the past, experiments were offered in every course, but the experimental projects were mostly verification experiments of single knowledge points.

Now, according to the new teaching model, it the experiment process changed into the form of comprehensive experiments of multiple courses, and the multidisciplinary knowledge is integrated into the experimental and practical projects. And the new mode emphasizes the independence of experimental design, that means the preparation of the experiment, the experimental process, the analysis of experimental results and the report of the experimental should be conducted in the way of group discussion and the guidance of teachers. No more the less, it also would carry out academic communication Actively such as seminars on knowledge application, lectures on advanced technologies, and exchange activities on innovative, so as to bring innovative awareness into the learning of each knowledge point.

\section{G. Three transformations realized into teaching method}

Adhering to the student-centered teaching philosophy, the method that teacher taught the principle first and then operated the demonstration in the experiment or training course should be changed, instead of making the experiment implementation plan by students themselves, and then evaluating the feasibility of the plan and giving correction advice by teacher, which transform teachers' passive indoctrination into students' independent thinking. The teacher emphasizes the matters needing attention in equipment operation in the specific experiment, the students finish the experiment process independently, which transform imitating operation into selfdesigned; the experimental project should be optimized, and the comprehensiveness and designability should be emphasized, which transform simple theory into verifying and analyzing the problems. As far as "three transformations" are concerned, some regular teaching activities such as teaching method discussion, teaching demonstration and experimental project optimization demonstration should be carried out.

\section{H. The standard of "double-qualified" applied to teaching staff}

It is a precondition, cultivating and forging "doublequalified" teacher staff, who possess not only a wealth of knowledge in his area of expertise, but also a certain engineering background and strong engineering application ability, of implementing applied major education. For this reason, engineering technicians who possess a good engineering quality and practical ability and work in the front line of engineering should be invited to take a part-time job, and participate in the discussion of practical teaching guidance, talent training program formulation, teaching content and implementation plan in the school, some engineering projects should also be introduced into school to involve teachers and students in research and implementation; at the same time, the school also sends outstanding teachers to well-known 
enterprises for training, to improve their engineering analysis and practice ability.

\section{CONCLUSION}

The practical teaching should be emphasized in the construction of electrical engineering and automation specialty, the construction of practical teaching idea, training mode, teaching content, teaching methods and construction of teaching staff should be reformed boldly and progressively, which is based on the market demand for talents, only in this way can we cultivate the practical talents that the society really needs. The thoughts and measures of the practical teaching reform of electrical engineering and automation specialty in XI'AN international university can provide reference for the practical teaching reform of training of engineering applied talents in other majors or universities. It is still a long way to go to build a first-class major, which requires continuous efforts, innovation and continuous improvement.

\section{REFERENCES}

[1] Peigen Li, Xiaodong $\mathrm{Xu}$, Guosong Chen. On Practical Teaching of Undergraduate Engineering Education in China: Problems and Cause [J], Research in Higher Education of Engineering, 2012(3): 1-6.

[2] Kekuan Liu. The highlight of construction of practical teaching system [J], China Higher Education Research, 2011(17): 40-41.

[3] Daolai Geng. Promoting higher education to create greater value for economic society and learners' development-the head of the development planning division of the ministry of education answers questions on the transformation and development of some universities[EB/OL].(2015.11.16)

http://www.moe.gov.cn/jyb_xwfb/s271/201511/t20151115_219011.html

[4] Qi Shen, Yan Zhang, Yang Lou. Construction and Reform of Application-oriented Undergraduate Practice Teaching System [J], Experimental Technology and Management. 2010, 27(10): 36-38.

[5] FU Xing-feng, ZHANG Chang-nian, YIN Tian-guang, XIAO Xiuling Construction of the Practical Teaching System for Cultivating Applied Talents [J], Researching and Exploration in Laboratory, 2011, 30(6): 148-150.

[6] Jun Liu. Research on talent's training mode of university-enterprise cooperation in application-oriented undergraduate college and universities under background of "Internet+" [J], Experimental Technology and Management, 2017, 34(6): 172-176. 